\title{
A case of severe channel-morphology change due to human influences in the Touqian River, Taiwan
}

\author{
M.-W. Huang \\ Disaster Prevention and Water Environment Research Center, National Chiao Tung University, Taiwan \\ K.-W. Li, J.-J. Liao \& Y.-W. Pan \\ Department of Civil Engineering, National Chiao Tung University, Taiwan \\ D.-H. Lee \\ Department of Civil Engineering, National Cheng Kung University, Taiwan
}

\begin{abstract}
One reach that locates in the midstream of the Touqian River in northern Taiwan was subjected to various human disturbances; the channel morphology in the reach changed severely as a result. This case study looks into the role of human disturbance on channel evolution by exploring the chronological change in channel morphology due to human influences in the studied reach. The major human influences in this reach include gravel mining, bridge construction and its protection works, and weir construction. Channel morphology downstream the bridge was transformed from an alluvial channel to a bedrock channel since the installation of a massive protection work. Later on, the bridge and its protection work were broken in recent years. After their failure, the reach started to take re-deposition and has returned to an alluvial channel. Chronological data including aerial photographs, cross-section surveys and hydrological data were compiled and analyzed. Also, field geology was conducted to characterize the distribution of bedrock outcrop and the erosion processes in the studied reach. According to the study results, the maximum depth of bedrock incision exceeds 15 meters. Main influences can be attributed to various human activities and the low resistance of young sedimentary rocks to erosion. The case study, as a fine example, demonstrates the processes of channelmorphology change due to human disturbances.
\end{abstract}

\section{INTRODUCTION}

Human influences have had a significant impact on many Taiwanese rivers. These influences have accumulated and combined from various activities such as dam construction, gravel mining, flow diversion, levee construction, water extraction, and infrastructure construction. Instream dams are likely to trap sediment and regulate flow discharge downstream, causing scour below the dam and a reduction in channel capacity (Kondolf, 1997). Gravel mining takes away the stream bed armouring materials, which might induce riverbed incisions and the undermining of the foundations of bridges and other structures (Kondolf, 1994). Flow diversion and water extraction decrease the river discharge and may induce channel aggradation. Levee and embankment construction may increase the flow velocity and induce scour around bridge piers at bridge crossings (Gregory, 2006). Numerous examples of riverchannel evolution as a result of human influence have been studied worldwide, enhancing the understanding of the effects of anthropogenic changes on channel adjustments (Surian \& Rinaldi, 2003; Downs et al., 2013; Nardi \& Rinaldi, 2015; Reid \& Brierley, 2015).
Channel incisions in bedrock or mixed bedrockalluvial channels are usually very slow based on long-term average rates (Tinkler \& Wohl, 1998). However, the erosion rate in soft bedrock rivers may be rapid and dominate the channel-morphology changes (Huang et al., 2013; Liao et al., 2013; Lai et al., 2011). The geological province of the Western Foothills in Taiwan is composed of Late Cenozoic sedimentary rock which is usually weak and poorly cemented. Many rivers in western Taiwan have suffered from the problem of soft bedrock incisions in the reaches that flow through the Western Foothills. The cases of rapid bedrock erosion in the Taan River and the Bachang River due to the coseismic uplift and the human influences have been studied to understand their morphologic evolutions (Huang et al., 2013; Huang et al., 2014).

This paper presents the case of severe channelmorphology change due to human influences in the Touqian River. It looks into the role of human disturbance on channel evolution by exploring the chronological change in channel morphology due to human influences in the studied reach. 


\section{SITE BACKGROUND}

The Touqian River is a major river in northern Taiwan. Its drainage basin is $565 \mathrm{~km}^{2}$ with a trunk length of $63 \mathrm{~km}$ approximately. The length of the reach covered in this study is about $4 \mathrm{~km}$, located about 12 to $16 \mathrm{~km}$ from the river mouth (Figure 1). The peak discharge recorded in the reach is 8560 $\mathrm{m}^{3} / \mathrm{s}$, which occurred in July 2013 during typhoon Soulik. The average discharge within the reach over the period $1990-2014$ is $20.24 \mathrm{~m}^{3} / \mathrm{s}$ (WRA, 2014).

The channel originally had several meters thick of alluvial deposits. Owing to human activities, the alluvial deposits gradually disappeared, exposing the underlying bedrock. The bedrock is composed of sandstone, shale, and interlayered sandstone and shale of the Pliocene-Pleistocene Toukoshan Formation. The active Hsincheng fault crosses the river a few hundred meters downstream the Chungcheng Bridge.

Major human activities have affected the reach including: 1) gravel mining in 1970s-1990s; 2) the Chungcheng Bridge and its protection works; 3 ) the Longen weir (Figure 1). In addition to these anthropogenic changes, there are a number of other structures, including five bridges and levees, that might also contribute, to a lesser degree, to the effects leading to the observed changes to the channel in this reach. However, the channel changes were dominated by the three major human activities that will be presented in this study.

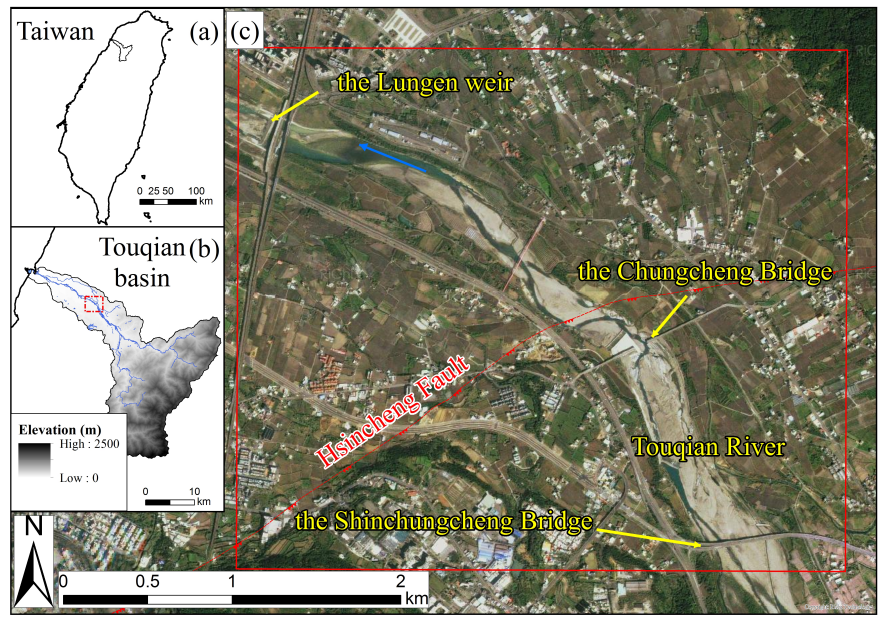

Figure 1. Site location map.

\section{HISTORICAL TOPOGRAPHIC DATA}

Aerial photographs are widely used for characterizing geomorphological change (Schiefer \& Gilbert, 2007; Huang et al., 2014). The topographic data used in this study included 6 sets of aerial photographs obtained in 1978, 1985, 1997, 2003, 2014, 2015 and 3 sets of cross-sectional survey data collected in
2005, 2008, 2012. Multi-stage digital surface models (DSM) and aerial orthophotographs (Figure 2) are derived from the aerial photographs using a commercial program with a set of ground control points (GCP). The aerial photographs in dry season are selected in order to obtain the maximum exposed area of channel bed. The cross-sections were surveyed by the river management agency for understanding the lateral channel topography including the inundated channel area every $500 \mathrm{~m}$ distance along longitudinal channel direction. The chronological aerial orthophotographs are used to observe the changes of channel planform. The digital surface models and the cross-sectional survey data are both used to quantify the changes in longitudinal channel direction.

\section{HUMAN INFLUENCES AND CHANNEL CHANGES}

According to the observation from the historical aerial photographs and the field investigations after large typhoons, we concluded that the intensive gravel mining, the Chungcheng Bridge and its protection works, and the Longen weir were the three major factors of anthropogenic changes influencing this reach. Each of these major factors were summarized chronologically in the following.

Gravel mining started in the 1970s in this reach. The patterns due to bar skimming and mining pits can be observed in the middle of the reach in the 1978 photograph presented in Figure 2. The footprint of the gravel mining had become widespread across the entire reach by the time of the 1985 orthophotograph. Finally, the gravel mining was banned in 1997 because of the global channel degradation and the safety impacts to the various infrastructures within the river.

The Chungcheng Bridge located in the middle of the reach and was completed in 1982. According to the borehole logging, the thickness of the alluvial deposits in the bridge area was 4-12 meters. Owing to the channel degradation and scouring, the bridge piers and substructures were substantially exposed and endangering the bridge. A series of protection works for the bridge were carried out, but then destroyed by flood flows caused by typhoons. The construction of the bridge protection works can be divided into the following three sequences:

1. A series of concrete block placements and the construction of concrete pavements were undertaken: protection works were carried out in $1986,1988,1989,1991$, and 1995, respectively. The large-area concrete pavements were severely damaged by the flood due to typhoon Herb in 1996, and furthermore the maximum depth of riverbed incision reached 5.5 meters in some pier surroundings. 
2. The first massive protection works (2003 in Figure 2): After typhoon Herb in 1996, a three-stage concrete gravity dam with a piled foundation was built as protection works downstream of the bridge. In addition, concrete pavements and side walls were also built to enclose the entire area of the bridge piers. This massive structure gradually collapsed from the downstream side due to local scouring and riverbed incision. The downstream third-stage pavement and piles were broken during typhoon Aere in 2004 (Figure 3 top). After the 2008 wet season, two of the threestage protection works were severely damaged (Figure 3 bottom). Emergency protection works were started construction in 2008, destroyed during typhoon Morakot in 2009, and finally completed in 2009. However, these emergency protection works were not longlasting and were destroyed during typhoon Saola in 2012. One of the Chungcheng Bridge pier foundation was exposed in the deep incised riverbed after typhoon Saola in 2012 (Figure 4 top).

3 . The second massive protection works (2014 in Figure 2): After typhoon Saola in 2012, another three-stage concrete gravity dam with piled foundation was built to protect the bridge. The massive concrete structure did not enclose the region of the exposed pier; instead, the channel was diverted away from the right bank to flow over the protection works. However, the channel diversion was not successful and severe damage was caused to the bridge during typhoon Soulik in 2013. The exposed pier and two segments of the bridge decks were removed during the typhoon (Figure 4 bottom). Afterward, the Chungcheng Bridge was rebuilt by the type of a long-span cable bridge to cross the widening and deepincised main channel.

The Lungen weir located downstream of the reach and was completed in 1998 (2003 in Figure 2). The weir is a low dam combined with two types of concrete structure: a 40 meters long overflow dam and a 160 meters long semi-permeable dam. It sets a new base level in the reach.

The channel changes are closely related to and affected by the human activities described above. The morphological evolution of the reach can be derived clearly from historical aerial photographs (Figure 2). In 1978, the braided channel consisted of multiple small channels and abounded with alluvial deposits. Intensive gravel mining had comprehensively changed the original channel morphology by 1985 . Then the local scouring downstream of the bridge protection works induced large area erosion leading to the exposure of the bedrock. The channel bedrocks belong to young sedimentary rocks and dis- turbed by the active fault are not resistant to flow erosion. The channel downstream of the bridge transformed rapidly from an alluvial-type channel to a gorge-type channel by 2003 . The failure of the protection works caused the upstream deposit materials to be transported downstream in considerable quantities. Then, the downstream reach abounded with alluvial deposits again, but oppositely in upstream reach that the riverbed started exposed owing to the armor material loss and suffered severe erosion from the processes of knickpoint migration in 2014 (2014 in Figure 2; Figure 4).

In addition to the changes to the channel planform, the historical channel change could also be analyzed in the longitudinal channel direction. Figure 5 presents the longitudinal profiles derived from the cross-section survey data and digital surface model for the reach. The channel changes can be divided into the following stages:

1. Global channel degradation caused by intensive gravel mining from 1978 to 1985 . This lead to the riverbed elevation being decreased by $2-6 \mathrm{~m}$.

2. A series of protection works built downstream of the Chungcheng Bridge between 1985 to 2012. Local scouring was extremely active downstream of the bridge. The maximum erosion depth was up to $15 \mathrm{~m}$, whilst upstream of the bridge, there was no significant change in riverbed elevation.

3. The construction of the Lungen weir set a new local base level downstream of the reach, and caused sediment deposition upstream of the weir.

4. A new channel developed close to the right bank (after 2012). The 2013 Soulik typhoon widened the new main channel, and sediments were transported from upstream to downstream. The event caused the headward erosion of rock river-bed and channel knickpoint migration.

\section{DISCUSSION AND CONCLUSION}

Based on the results of a field geological investigation, the bedrock orientation varies along the channel longitudinal direction. The bedrock is dipping upstream in both downstream and upstream areas of the bridge, and is dipping to the right bank direction in the vicinity of the bridge. In lithology, the bedrock is composed of sandstone, shale and interlayered sandstone and shale. According to the results from an investigation, the value of the erodibility index (Annandale 1995) for the sandstone is about 4 times larger than the values for both the shale and interlayered sandstone and shale. The results indicate that the bedrock is composed of strong layers and weak layers to the erosion. Combination of the orientation 
factor and the lithology factor, the erosion processes of soft rock river-bed included: 1) uniform incision, plucking, bedload abrasion occurred from 200 meters upstream the bridge; 2) trenching incision and plucking, which were observed from the Chungcheng Bridge to 200 meters upstream the bridge; 3) local scouring downstream the bridge was initially incised along the weak layer and then extended.

The channel slope before the construction of the Chungcheng was about $1 / 150$. The bridge protection works fixed the elevation of the bridge riverbed, and induced the local scouring that greatly changed the channel slope. Now the new main channel developed close to the right bank of the bridge, the channel slope was readjusted smoothly. However, the average slope upstream the bridge is still much larger than the slope downstream that indicates the erosion processes would be still active headward.

In this study, the changes in channel morphology within the reach are strongly affected by the human activities, principally, gravel mining, the Chungcheng Bridge and its protection works, and the Longen weir. The exposed bedrock was severely eroded by different erosion processed leading to significant channel changes. The channel downstream of the bridge transformed rapidly from an alluvialtype channel to a gorge-type channel in only a few decades. Main influences can be attributed to various human activities and the low resistance of young sedimentary rocks to erosion.

\section{REFERENCE}

Annandale, G. W. (1995) Erodibility. Journal of Hydraulic Research, 33, 471-494.

Downs, P. W., Dusterhoff, S. R. \& Sears, W. A. (2013) Reachscale channel sensitivity to multiple human activities and natural events: Lower Santa Clara River, California, USA. Geomorphology, 189, 121-134.

Gregory, K. J. (2006) The human role in changing river channels. Geomorphology, 79, 172-191.

Huang, M.-W., Liao, J.-J., Pan, Y.-W. \& Cheng, M.-H. (2014) Rapid channelization and incision into soft bedrock induced by human activity - Implications from the Bachang River in Taiwan. Engineering Geology, 177, 10-24.

Huang, M.-W., Pan, Y.-W. \& Liao, J.-J. (2013) A case of rapid rock riverbed incision in a coseismic uplift reach and its implications. Geomorphology, 184, 98-110.

Kondolf, G. M. (1994) Geomorphic and environmental - effects of instream gravel mining. Landscape and Urban Planning, $28,225-243$

Kondolf, G. M. (1997) Hungry water: Effects of dams and gravel mining on river channels. Environmental Management, 21, 533-551.

Lai, Y. G., Greimann, B. P. \& Wu, K. W. (2011) Soft bedrock erosion modeling with a two-dimensional depth-averaged model. Journal of Hydraulic Engineering-ASCE, 137, 804814.

Liao, C.-T., Yeh, K.-C. \& Huang, M.-W. (2013) Development and application of 2-D mobile-bed model with bedrock river evolution mechanism. Journal of Hydro-environment Research.
Nardi, L. \& Rinaldi, M. (2015) Spatio-temporal patterns of channel changes in response to a major flood event: the case of the Magra River (central-northern Italy). Earth Surface Processes and Landforms, 40, 326-339.

Reid, H. E. \& Brierley, G. J. (2015) Assessing geomorphic sensitivity in relation to river capacity for adjustment. Geomorphology, 251, 108-121.

Schiefer, E. \& Gilbert, R. (2007) Reconstructing morphometric change in a proglacial landscape using historical aerial photography and automated DEM generation. Geomorphology, $88,167-178$.

Surian, N. \& Rinaldi, M. (2003) Morphological response to river engineering and management in alluvial channels in Italy. Geomorphology, 50, 307-326.

Tinkler, K. J. \& Wohl, E. E. (1998) A primer on bedrock channels. IN TINKLER, K. J. \& WOHL, E. E. (Eds.) River over rock: Fluvial processes in bedrock channels. Washington, DC, American Geophysical Union.

Water Resources Agency (2014) Hydrological year book of Taiwan. Taiwan. 


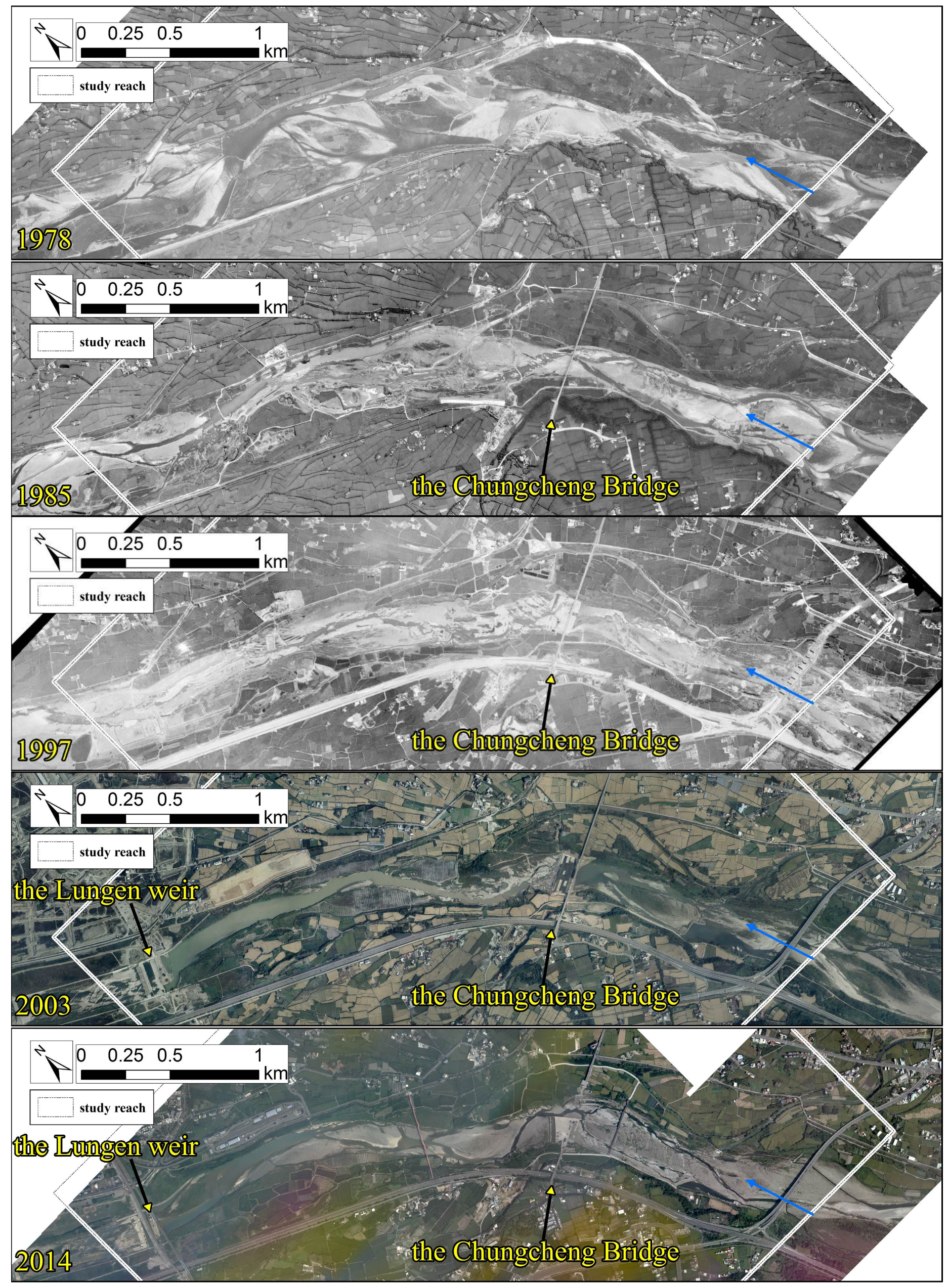

Figure 2. Historical aerial orthophotographs of the study reach: 1978, 1985, 1997, 2003, and 2014 from top to bottom. 


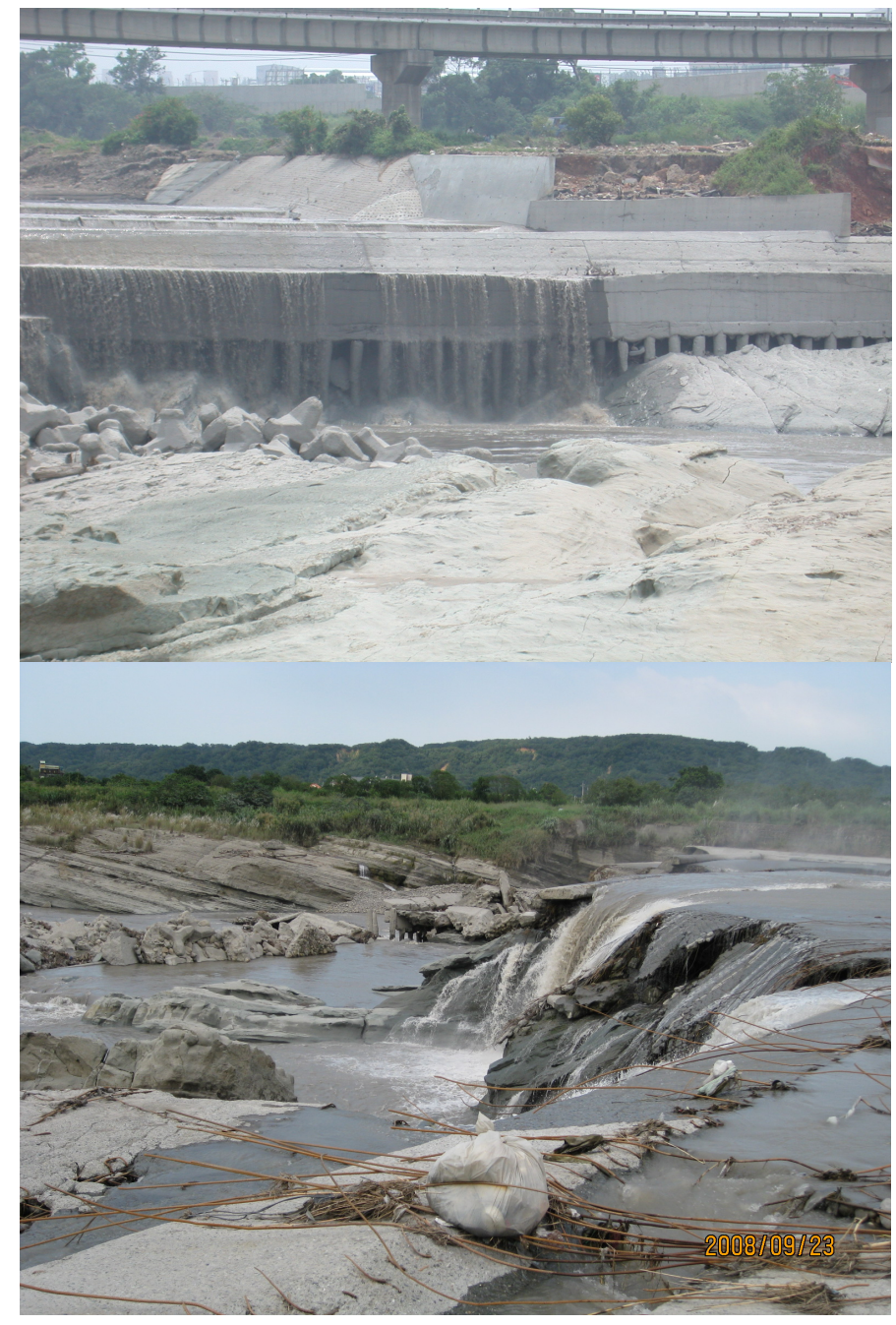

Figure 3. Damaged conditions of the first massive protection works of the Chungcheng Bridge in September 2004 (top) and September 2008 (bottom).

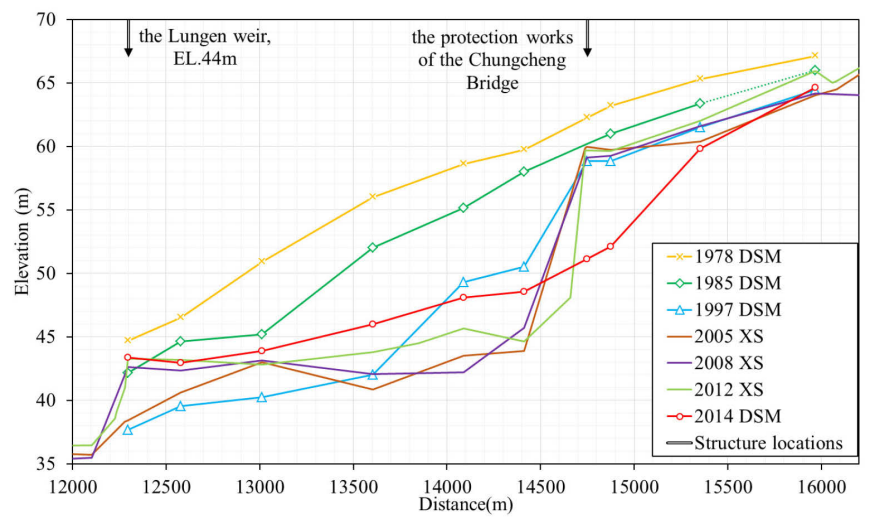

Figure 5. The historical longitudinal profiles of the study reach.
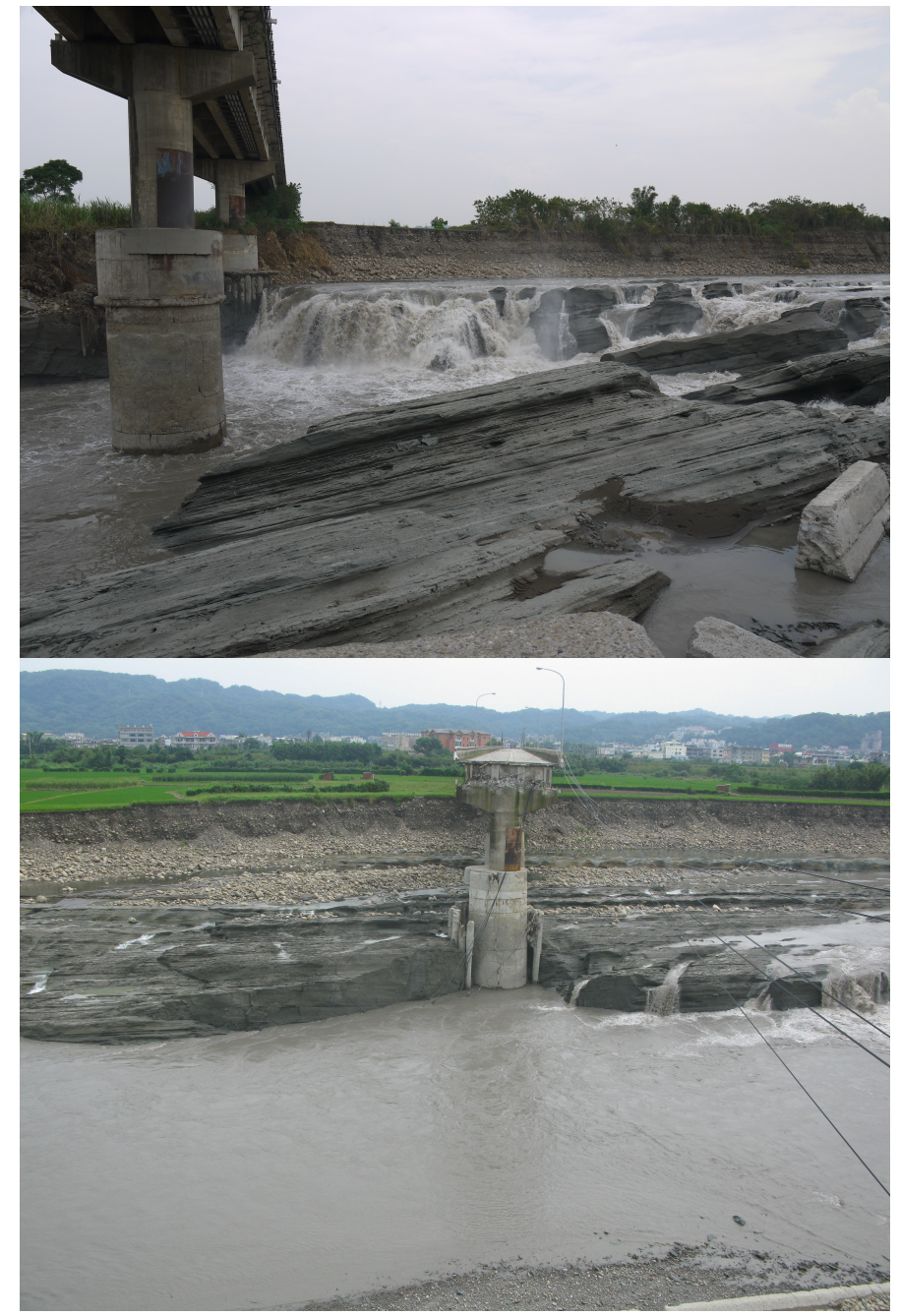

Figure 4. The protection works of the Chungcheng Bridge were destroyed leading to a bridge pier to be exposed completely after typhoon Saola in 2012 (top); the exposed pier and two segments of the bridge decks were removed during typhoon Soulik in 2013 (bottom). 